\title{
31
}

\section{Endocrine Regulation of Phosphate Homeostasis}

\author{
Ronald B. Brown ${ }^{1}$, Mohammed S. Razzaque $2,3,4,5$
}

${ }^{1}$ University of Waterloo, Waterloo, ON, Canada; ${ }^{2}$ Forsyth Institute, Cambridge, MA, United States; ${ }^{3}$ University of Rwanda School of Dentistry, Kigali, Rwanda; ${ }^{4}$ Harvard School of Dental Medicine, Boston, MA, United States; ${ }^{5}$ Lake Erie College of Osteopathic Medicine, Erie, PA, United States

\section{O U T L I N E}

1. Introduction

2. Phosphate Homeostasis

2.1 Intestinal Phosphate Absorption

2.2 Renal Phosphate Reabsorption

2.3 Skeletal Phosphate Resorption

3. Endocrine Regulatory Factors

3.1 Parathyroid Hormone

3.2 Vitamin D

3.3 Fibroblast Growth Factor 23 and Klotho
539

540

540

541

541

541

541

541

542
4. Dysregulation of Phosphate Homeostasis

4.1 Genetic Disorders of Phosphate Regulation

4.2 Conditions Associated With Phosphate Toxicity

4.2.1 Chronic Kidney Disease

4.2.2 Vascular Calcification

4.2.3 Tumorigenesis and Premature Aging

5. Conclusion

References
542

543

543

544

544

544

545

545

\section{INTRODUCTION}

The importance of phosphate regulation in the human body has been highlighted by research showing that phosphate dysregulation is associated with many disease conditions, including chronic kidney disease (CKD), cardiovascular disease, tumorigenesis, premature aging, and skeletal disorders. ${ }^{1-8}$ The benefit of dietary phosphate restriction in the management of CKD is well established. ${ }^{9-11}$ However, until recently, little attention has focused on the health and disease consequences of an oversupply of phosphorus in the diet of healthy adults. Recent epidemiological research has shown that mortality in healthy adults increases as dietary phosphate intake levels rise above $1400 \mathrm{mg}$ per day. ${ }^{12}$ Paradoxically, the United States Department of Agriculture continues to recommend dietary phosphate levels exceeding $1700-1800 \mathrm{mg}$ per day for a 2000-calorie diet. ${ }^{13,14}$ Thus, issues of phosphate homeostasis apply to the general population, not just to patients with CKD.

In this book chapter, we outline the physiological basics of phosphate homeostasis, focusing particularly on endocrine regulation of this essential micronutrient - the second most abundant mineral in the body, next to calcium. The first part discussed at the intestinal absorption and regulation of phosphate homeostasis through the bone-kidney axis, the next part explained in more detail at the interaction of specific endocrine regulators of phosphate homeostasis, and the last part elaborated some of the pathophysiological conditions associated with dysregulated phosphate homeostasis. 


\section{PHOSPHATE HOMEOSTASIS}

The regulation of phosphate homeostasis is biologically important because inorganic phosphorus performs many functions within the body. ${ }^{15-19}$ Phosphate is a component of nucleic acids, DNA and RNA, and it is incorporated in the structure of phospholipids in cell membranes. As an intracellular anion, phosphate is involved in the activation and inactivation of enzymes and coenzymes. Phosphate also plays roles in cell signaling through phosphorylation, in energy metabolism as ATP, and in bone mineralization as a principal element within hydroxyapatite. Endocrine regulation of phosphate depends on a delicate balance among circulating factors like $1,25(\mathrm{OH})_{2} \mathrm{D}_{3}$ (calcitriol, the active form of vitamin D), parathyroid hormone (PTH), and fibroblast growth factor 23 (FGF23). Dysregulation of these factors can induce phosphorus imbalances which can affect the functionality of almost every human system, including musculoskeletal and cardiovascular systems, ultimately leading to an increase in morbidity and mortality. Through the action of PTH, vitamin D, and FGF23, phosphate homeostasis is maintained by regulating the amount of phosphate absorbed in the intestines, reabsorbed in the kidney, and resorbed from bone (Fig. 31.1).

\subsection{Intestinal Phosphate Absorption}

Phosphate from dietary sources is absorbed in the small intestines, mainly through active transport by the type II sodium-dependent phosphate cotransporter, Npt2b (encoded by gene SLC34a2), and absorption is regulated by hormones and dietary conditions. ${ }^{20-22}$ The sodium and phosphorus ions are transported by the Npt2b cotransporters, which involves voltage-dependent and electroneutral mechanisms. In addition to $1,25(\mathrm{OH})_{2} \mathrm{D}_{3}$, factors that regulate the expression and function of Npt2b include FGF23, matrix extracellular phosphoglycoprotein (MEPE), epidermal growth factor (EGF), thyroid hormone, estrogens, glucocorticoids, and metabolic acidosis. Moreover, $\mathrm{Na}^{+} / \mathrm{H}^{+}$exchange regulatory factor 1 (NHERF1) also interacts with $\mathrm{Npt} 2 \mathrm{~b}$ in the intestines under conditions of low dietary phosphorus intake. ${ }^{23} \mathrm{~A}$ smaller amount of phosphorus is believed to be absorbed in the intestines by type III sodium-dependent phosphate cotransporters, Pit1 and Pit2, which operate by passive transport and are involved in functions of individual cells. ${ }^{22}$ In addition, ingestion of large amounts of dietary phosphate can increase serum phosphate levels through increased absorption via a paracellular route, bypassing hormonal regulation of cotransporters. ${ }^{22,24}$

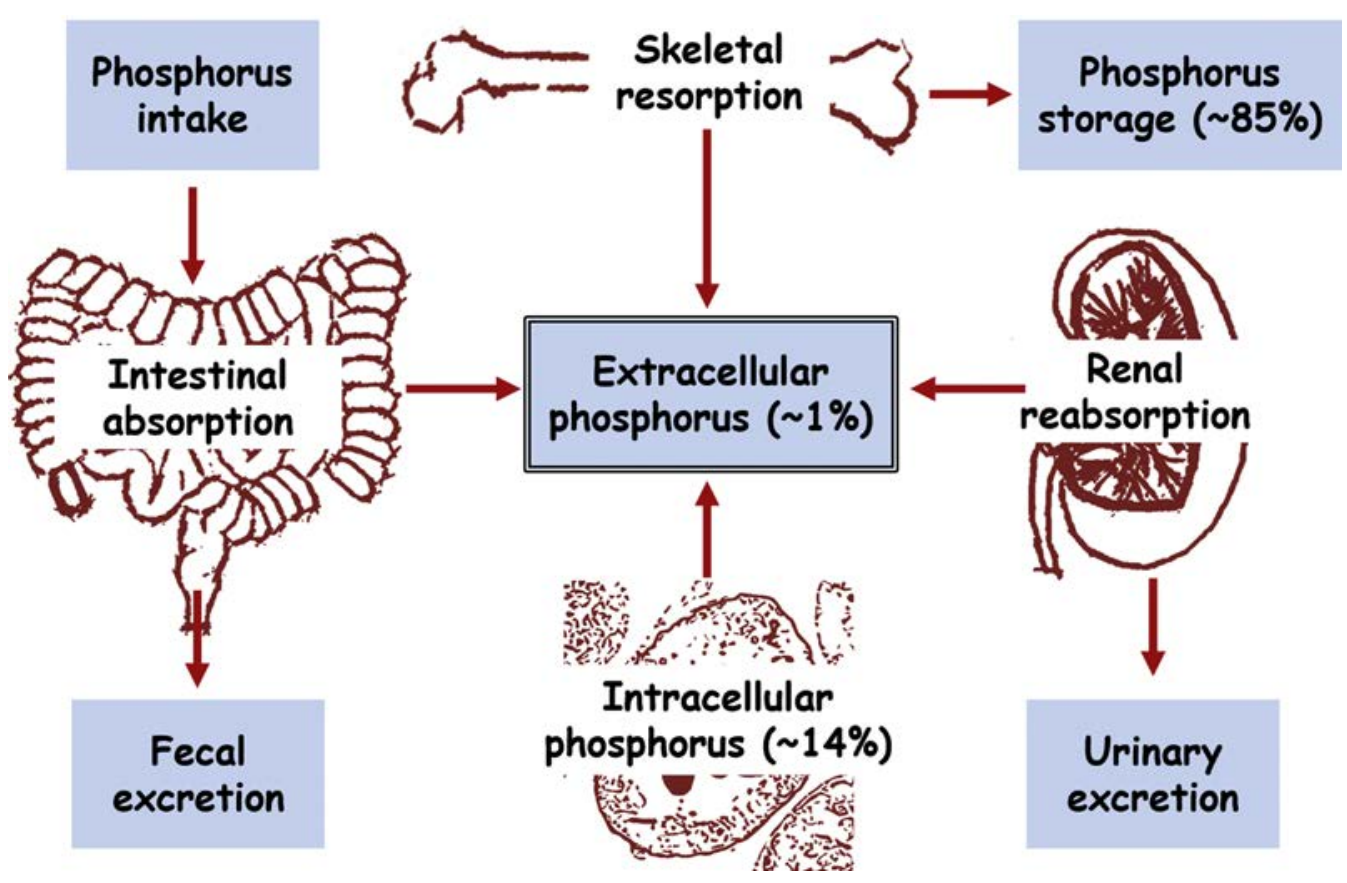

FIGURE 31.1 Total body phosphorus homeostasis is primarily maintained by a multiorgan cross-talk among parathyroid gland, intestine, kidney, and bone. Of clinical importance, since only $1 \%$ of total body phosphorus is extracellular, the serum phosphorus concentration does not truly reflect total body phosphorus content and is also a poor predictor of intracellular and storage phosphorus content. ${ }^{19,120,127,133,135}$ 


\subsection{Renal Phosphate Reabsorption}

Serum phosphate levels are regulated mainly through the reabsorption rate of renal phosphate within the kidney, the major organ that regulates phosphate homeostasis according to the body's requirements. ${ }^{5,18,25}$ Renal phosphate reabsorption increases or decreases through the expression of sodium-phosphate cotransporters, Npt2a (SLC34a1) and Npt2c (SLC34a3), located in the renal proximal tubule. ${ }^{26} \mathrm{Npt} 2 \mathrm{a}$ is electrogenic and transports three $\mathrm{Na}^{+}$ions coupled to phosphorus $\left(\mathrm{HPO}_{4}{ }^{2-}\right)$ at physiologic $\mathrm{pH}$, while $\mathrm{Npt} 2 \mathrm{c}$ is electroneutral and transports two $\mathrm{Na}^{+}$ions for each phosphorus ion. Pit2 phosphate transporters are also located in the renal proximal tubule. It is believed that a low concentration of sodium regulated by $\mathrm{Na}^{+}, \mathrm{K}^{+}$-ATPase in the cells of the basolateral membrane facilitates phosphorus transport within the proximal tubule. ${ }^{27-31}$ Cotransporters import phosphate from the proximal tubular lumen, translocated across the apical brush-border membrane (BBM) and exported at the basolateral membrane. ${ }^{26}$ Although the molecules involved in phosphate translocation have not been identified, xenotropic and polytropic retrovirus receptor 1 (XPR1) appears to act as a phosphate exporter in mammalian cells, but its role as an exporter in renal cells has not yet been determined.

Hyperphosphaturia and hypophosphatemia occur in Npt2a knockout mice (Npt2a $\left.\mathrm{a}^{-/}\right)$. Concentrations of serum $1,25(\mathrm{OH})_{2} \mathrm{D}_{3}$ and urine calcium also increase in Npt2a knockout mice; there is a $\sim 70 \%$ decrease in phosphate transport in the BBM, and reabsorption is supported by increased expression of Npt2c. ${ }^{32-35}$ This evidence indicates that Npt2a in mice is a major transporter in renal phosphate reabsorption. Mutation of Npt2a in humans causes recessive Fanconi syndrome with hypophosphatemic rickets, suggesting that Npt2a plays a role in phosphate handling. ${ }^{36,37}$ In Npt2c knockout mice, (Npt2 $\left.\mathrm{c}^{-/-}\right)$, hypercalciuria and higher serum concentrations of $1,25(\mathrm{OH})_{2} \mathrm{D}_{3}$ occur, but hypophosphatemia or rickets does not. ${ }^{34}$ The situation is different in humans with mutation of Npt2c, causing hereditary hypophosphatemia rickets with hypercalciuria $(\mathrm{HHRH})$, which suggests that $\mathrm{Npt} 2 \mathrm{c}$ has a more important role in phosphate homeostasis in humans than in mice. ${ }^{38,39}$

\subsection{Skeletal Phosphate Resorption}

Bone functions as a reserve for calcium and phosphate from which the body can deposit and withdraw minerals to maintain mineral ion balance. ${ }^{17,40-45}$ Reabsorption is the process by which bone releases calcium and phosphate from the hydroxyapatite bone matrix. Osteocytes in mature bone assist in bone mineralization and phosphate homeostasis by producing factors such as FGF23 and $1,25(\mathrm{OH})_{2} \mathrm{D}_{3}$. Other endocrine regulators that target bone include PTH, calcitonin, sex hormones, and osteocalcin. An endocrine communication network that regulates phosphorus homeostasis is formed between bone, kidneys, intestines, and parathyroid glands (Fig. 31.1).

\section{ENDOCRINE REGULATORY FACTORS}

\subsection{Parathyroid Hormone}

Phosphate reabsorption is decreased in the kidney by PTH, which induces phosphaturia. ${ }^{26}$ Decreased reabsorption occurs, as levels of Npt2a and Npt2c protein are reduced in the BBM. Through endocytosis, Npt2a is delivered to lysosomes for degradation, while Npt2c is dissolved through a pathway dependent on microtubules. The basolateral and apical surfaces of the proximal tubule each contain PTH receptors. On the apical surface, PTH receptors are signaled by a protein kinase C (PKC) pathway, and a protein kinase A (PKA) pathway signals PTH receptors on the basolateral surface. PTH signaling occurs by phosphorylation of NHERF1. ${ }^{4-49}$ Production of FGF23 is enhanced by PTH, and phosphate augments PTH production by stabilizing its mRNA. ${ }^{50-54}$

\subsection{Vitamin D}

More than $80 \%$ of required vitamin D in human is generated by ultraviolet (UV) B rays from sunlight. ${ }^{55-63}$ As mentioned, $1,25(\mathrm{OH})_{2} \mathrm{D}_{3}$ increases intestinal absorption of dietary phosphate, mainly through enhanced expression of Npt2b cotransporters. $1,25(\mathrm{OH})_{2} \mathrm{D}_{3}$ is produced from circulating 25-hydroxyvitamin $\mathrm{D}[25(\mathrm{OH}) \mathrm{D}]$ through the action of $1 \alpha$-hydroxylase (CYP27B1), an enzyme expressed in the renal proximal tubules. Janus kinase 3 (JAK3), produced in epithelial cells of the kidney, has also recently been found to powerfully regulate 1 $\alpha$-hydroxylase expression and phosphate transport. ${ }^{64}$ Although $1,25(\mathrm{OH})_{2} \mathrm{D}_{3}$ does not play a direct role in the reabsorption of renal phosphate, $1,25(\mathrm{OH})_{2} \mathrm{D}_{3}$ suppresses PTH synthesis, thus indirectly preventing reduced renal phosphate 


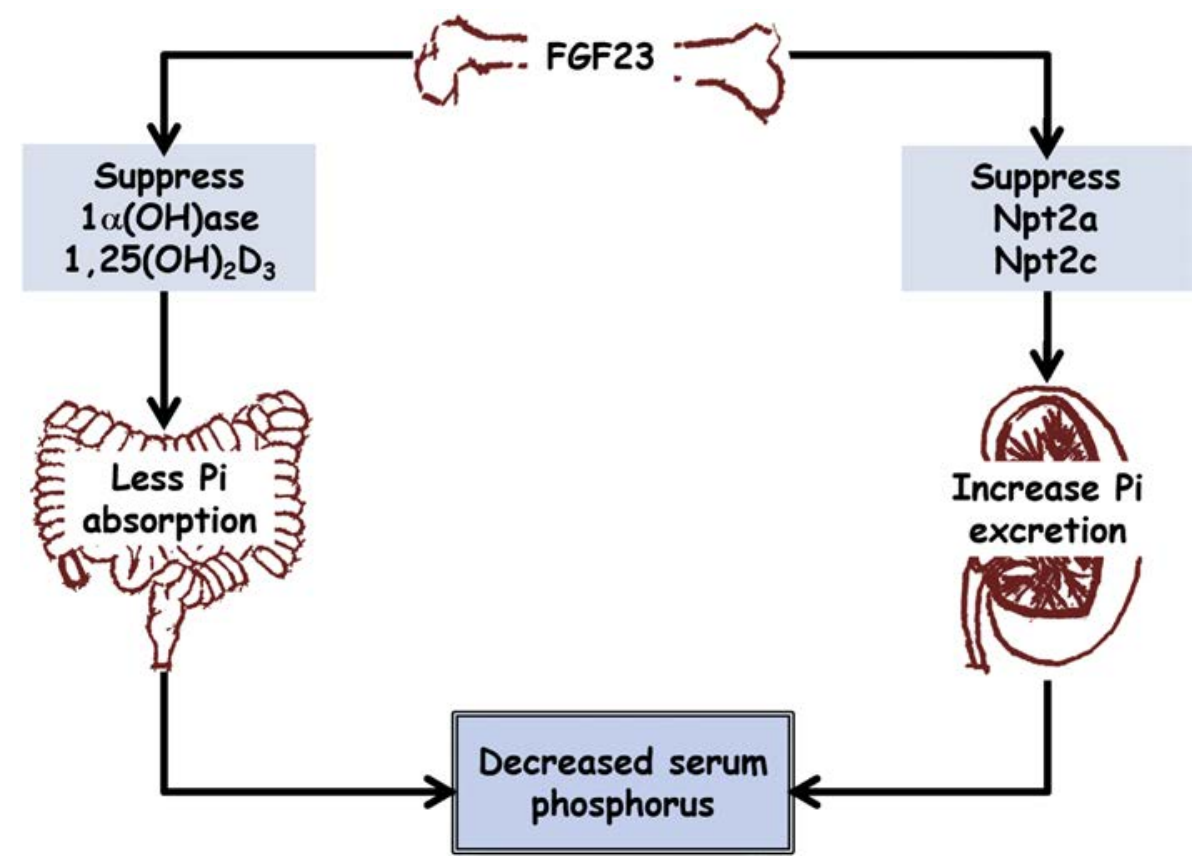

FIGURE 31.2 FGF23 produced in the bone can suppress Npt2a and Npt2c cotransporters to increase the renal excretion of phosphate. Similarly, FGF23 can also suppress the renal expression of $1 \alpha(\mathrm{OH})$ ase to reduce production of $1,25(\mathrm{OH})_{2} \mathrm{D}_{3}$ to decrease intestinal phosphate absorption, resulting in reduced serum levels of phosphate. . $19,132^{2}$

reabsorption caused by PTH. Rising serum phosphate levels suppress production of $1,25(\mathrm{OH})_{2} \mathrm{D}_{3}$, forming a feedback loop between intestinal absorption and serum phosphate. The FGF23 production also increases as serum levels of phosphate and $1,25(\mathrm{OH})_{2} \mathrm{D}_{3}$ rise.

\subsection{Fibroblast Growth Factor 23 and Klotho}

FGF23, produced by osteocytes and osteoblasts of bone, is a recently discovered regulatory factor in phosphorus homeostasis. ${ }^{65-69}$ Renal phosphate wasting is caused by excessive levels of FGF23 in the serum, and the discovery of FGF23's phosphate regulatory function was made after finding that autosomal-dominant hypophosphatemic rickets (ADHR) was caused genetically by mutations in the FGF23 gene. A member of the FGF19 subfamily, the FGF23 peptide in humans contains 251 amino acids, which is cleaved proteolytically during the secretion process. FGF23 requires a transmembrane protein cofactor, Klotho, which enables the activation of FGF receptors (FGFR).$^{70}$ Ectopic calcification, high levels of $1,25(\mathrm{OH})_{2} \mathrm{D}_{3}$, and hyperphosphatemia were discovered in the phenotypes of Klotho and FGF23 null mice. ${ }^{71-76}$ Upon activation, FGF23 lowers serum phosphate levels and increases phosphate excretion in the urine by suppressing reabsorption through the action of sodium-phosphate cotransporters, mostly in the renal proximal (Fig. 31.2). Klotho is expressed in the kidney, and Klotho-activated FGF23 reduces the expression of Npt2a, possibly by phosphorylating NHERF1. ${ }^{49}$

Within the renal proximal tubular epithelium, recent findings imply that FGF23 activates FGFR1 as well as FGFR4, which mediates signaling involving JAK3. ${ }^{49}$ In the distal tubular epithelium, FGF23 targets with-no-lysine kinase- 4 (WNK4) which regulates solute transport. ${ }^{15,49}$ FGF23 also downregulates synthesis of 1 $\alpha$-hydroxylase in the renal proximal tubules, thus suppressing $1,25(\mathrm{OH})_{2} \mathrm{D}_{3}$ production. As mentioned, the release of FGF23 from bone is stimulated by increased serum levels of both phosphate and vitamin D; thus, FGF23 provides a regulatory feedback loop between the kidneys and bone.

\section{DYSREGULATION OF PHOSPHATE HOMEOSTASIS}

The endocrine feedback loops that regulate serum phosphate is a complex process. When endocrine regulation of phosphate homeostasis becomes dysfunctional due to phosphate burden or injury from phosphate toxicity, or due to genetic abnormalities, several associated disease conditions result. In general, dysregulated serum phosphate falls 
TABLE 31.1 A List of Several Human Diseases With Abnormal Phosphate Balance Due to Dysregulation of FGF23

\begin{tabular}{ll}
\hline Diseases Associated With Increased FGF23 Activity & Cause \\
\hline ADHR & FGF23 mutation \\
ARHR & DMP1 mutation \\
ENS & FGFR3 mutation \\
McCune-Albright syndrome & GNAS1 mutation \\
OGD & FGFR1 mutation \\
TIO & FGF23-producing tumor \\
XLHR & PHEX mutation \\
\hline Diseases Associated With Decreased FGF23 Activity & Cause \\
\hline FTC & GALNT3 mutation \\
FTC & FGF23 mutation \\
FTC & KLOTHO mutation \\
\hline
\end{tabular}

Please note that the serum levels of both C-terminal and intact FGF23 are high in FTC caused by a KLOTHO mutation, while serum levels of C-terminal are high, the levels of intact FGF23 are low to normal in FTC caused by GLANT3 or FGF23 mutations. ${ }^{19,132}$

$A D H R$, autosomal dominant hypophosphatemic rickets; $A R H R$, autosomal recessive hypophosphatemic rickets/osteomalacia; DMP1, dentin matrix protein 1; ENS, epidermal nevus syndrome; FTC, familial tumoral calcinosis; GALNT3, UDP-N-acetyl-alpha-D-galactosamine:polypeptide N-acetylgalactosaminyltransferase-3; GNAS1, guanine nucleotide-binding protein alpha-stimulating activity polypeptide 1; OGD, osteoglophonic dysplasia; $P H E X$, phosphate-regulating gene with homology to endopeptidases on the X chromosome; TIO, tumor-induced osteomalacia; XLHR, X-linked hypophosphatemic rickets.

within two categories: hypophosphatemia and hyperphosphatemia. However, normal serum phosphate levels do not preclude intracellular and extracellular phosphorus dysregulation and associated conditions. ${ }^{4}$

\subsection{Genetic Disorders of Phosphate Regulation}

X-linked hypophosphatemic rickets (XLHR), ADHR, and autosomal recessive hypophosphatemic rickets (ARHR) occur when the FGF23 function is excessive. High circulating levels of FGF23 result in inadequate renal phosphate reabsorption and normal to lower levels of $1,25(\mathrm{OH})_{2} \mathrm{D}_{3}$. In addition to FGF23, genes that cause XLHR are phosphateregulating gene with homologies to endopeptidases on the $\mathrm{X}$ chromosome (PHEX), ectonucleotide pyrophosphatase/phosphodiesterase 1 (ENPP1), and dentin matrix protein 1 (DMP1) (Table 31.1).

Overexpression of FGF23 also causes hypophosphatemic rickets/osteomalacia associated with McCune-Albright syndrome, fibrous dysplasis, hypophosphatemic disease caused by intravenous administration of saccharated ferric oxide or iron polymaltose, family with sequence similarity 20, member C (FAM20C), and tumor-induced osteomalacia. ${ }^{77-79}$ In addition to releasing FGF23, mesenchymal tumors can synthesize and release other phosphaturic factors such as FGF7, MEPE, and secreted frizzled-related protein 4 (sFRP4). ${ }^{80-83}$ Hyperphosphatemic diseases occur when the FGF23 function is lacking due to inactivating mutations, e.g., familial tumoral calcinosis which produces elevated levels of renal phosphate reabsorption and $1,25(\mathrm{OH})_{2} \mathrm{D}_{3}$, along with ectopic calcification. ${ }^{84-87}$ In addition to FGF23 and Klotho, UDP-N-acetyl-alpha-D-galactosamine:polypeptide N-acetylgalactosaminyltransferase 3 (GALNT3) is the gene that causes familial tumoral calcinosis. ${ }^{85,88}$ Klotho mutations were found to cause resistance to FGF23, ${ }^{89}$ and mutations in GALNT3 and FGF23 impaired secretion and circulation of full-length FGF23.

\subsection{Conditions Associated With Phosphate Toxicity}

That excessive intake of dietary phosphate is largely absorbed and may bypass normal endocrine regulation suggests that humans, and perhaps other mammals, lack the physiological mechanisms to regulate a high-phosphorus diet. Many people, including patients with $\mathrm{CKD}^{90}$ and future medical professionals, ${ }^{91}$ lack awareness that a conventional Western diet, abundant in dairy, flesh foods, grains, and phosphate additives, far exceeds the recommended dietary allowances for phosphorus. Phosphate toxicity, the accumulation of excess phosphorus in the intracellular and extracellular tissues, whether from genetic disorders or excessive dietary phosphate intake, is associated with a wide variety of disease conditions. ., $^{2,93}$ 

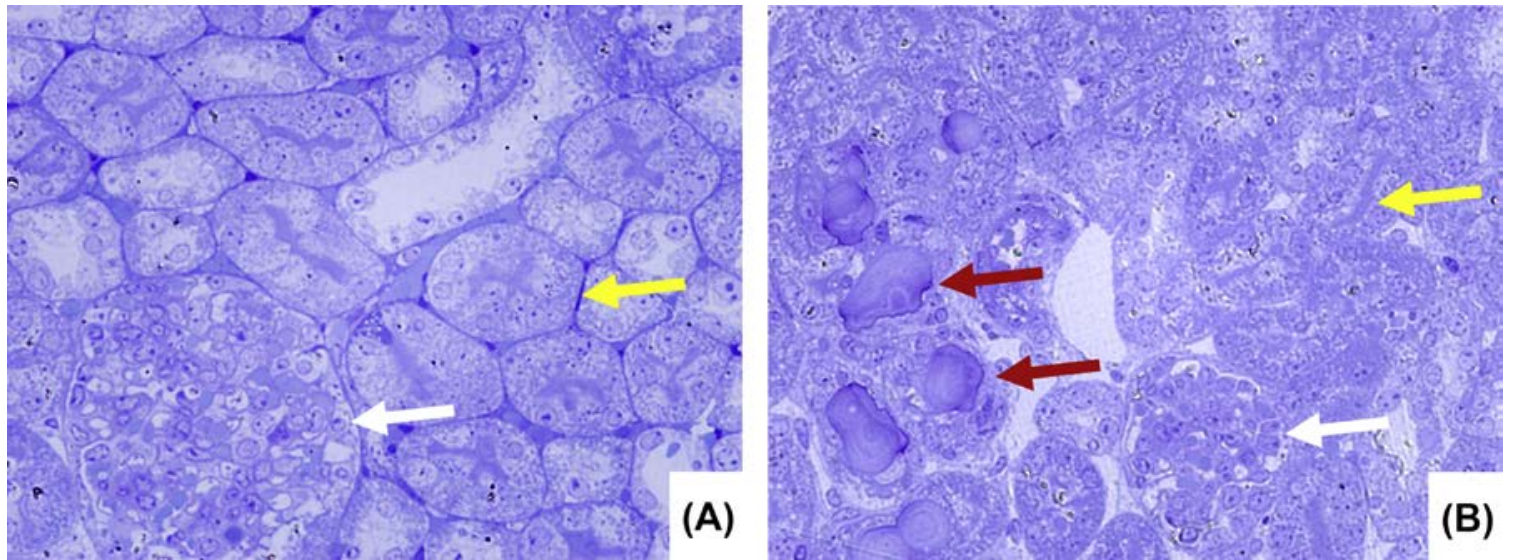

FIGURE 31.3 Ultrathin sections of kidneys of a mouse with normal serum phosphate level (A) and a mouse with high serum phosphate level (B). Please note the comparative glomerular structures (white arrows) and tubulointerstitial structures (yellow arrows) in kidneys with normal and high phosphate levels. The toluidine blue-stained kidney sections showing glomerular shrinkage, loss of tubulointerstitial uniformity, and renal calcification (red arrows) in kidney exposed with phosphate toxicity. ${ }^{120}$ (Original magnification $\times 40$ ).

\subsubsection{Chronic Kidney Disease}

High serum phosphorus concentrations have been shown to increase the risk of developing kidney disease. ${ }^{94}$ Increased renal phosphate burden causes tubular injury and interstitial fibrosis within the kidneys. ${ }^{1,95-97}$ As serum phosphorus increases in kidney disease patients, glomerular filtration rate decreases. Increased mortality from cardiovascular disease is also associated with CKD. ${ }^{98-102}$ Patients with early stages or end stage renal disease are counseled to manage their condition by following phosphate-restricted diets, and patients may also be prescribed phosphate binders. ${ }^{103,104}$

In hyperphosphatemia, phosphorus binds with free calcium to form calcium-phosphorus (CaxPi) product, a mineral compound normally elaborated into bone hydroxyapatite. ${ }^{2,92}$ The consequent serum reduction in free calcium stimulates release of the PTH which in turn resorbs bone to restore normal concentrations of serum calcium. This may explain how hyperphosphatemia in patients with CKD may induce secondary hyperparathyroidism, which accelerates bone resorption that may eventually lead to skeletal mineralization defects. The subsequent increase in serum concentration of CaxPi product, under continuing conditions of kidney burden that initiated hyperphosphatemia, may also be deposited into the tissue causing ectopic calcification (Fig. 31.3).

\subsubsection{Vascular Calcification}

The arterial system's endothelium is susceptible to ectopic calcification from CaxPi product deposition. Mortality risk is increased threefold to fourfold by arterial calcification. ${ }^{105}$ A hard or stable plaque forms in calcified arterial vessels, which is associated with hypertension, arteriosclerosis, left ventricular hypertrophy, and aortic valve disease. Vasodilation is also impaired by a high phosphorus load, which increases cardiovascular disease risk. ${ }^{106}$ High levels of serum phosphorus have been associated with coronary atherosclerosis, ${ }^{107}$ left ventricular hypertrophy, ${ }^{108-111}$ and a $40 \%$ increased risk of heart failure. ${ }^{112}$

\subsubsection{Tumorigenesis and Premature Aging}

Phosphorus is sequestered in tumors in cancer patients, ${ }^{113}$ and cancer cells accumulate up to twice as much phosphorus as normal cells. ${ }^{114}$ A cellular environment high in phosphorus in humans has been found to induce tumor neovascularization and angiogenesis, or new blood vessel formation in neoplasms, ${ }^{115}$ possibly playing a role in sequestering excess phosphorus, as does the hyphae of mycorrhizae in a plant's root system. ${ }^{116}$ Tumor growth in lung tissue has been stimulated by dietary phosphorus overload, ${ }^{117}$ and breast cancer cells cultured with elevated phosphorus levels were observed to modulate tumor metabolism and metastasis. ${ }^{118} \mathrm{~A}$ high daily phosphorus intake by men in the Health Professionals Follow-Up Study was associated with an increased overall risk of prostate cancer and with lethal and high-grade prostate cancer. ${ }^{119}$ Phosphate toxicity has been found to acceler-

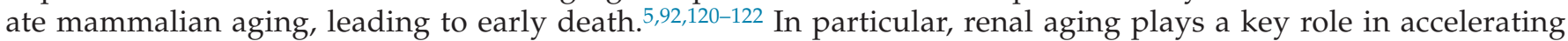
systemic aging. ${ }^{123-125}$ 


\section{CONCLUSION}

Recent studies have provided convincing evidence of endocrine regulation of systemic phosphate homeostasis. 2,19,92,120,126-128 The endocrine interaction between bone-derived FGF23 and kidney-derived Klotho is essential for physiologic regulation of phosphate homeostasis. As briefly discussed, dysregulation of the FGF23-Klotho system leads to phosphate imbalance and induces a wide range of organ/tissue damage in blood vessels, bone, and kidney. Of clinical significance, phosphate toxicity induced by exogenous phosphate administration in humans can be fatal. ${ }^{5}$ Recent studies have found that future medical professionals and CKD patients undergoing hemodialysis are not sufficiently aware of the hidden source of phosphate in their diet and highlight the need for educational initiatives to raise awareness of the risk posed by dietary items with hidden phosphate ingredients, $, 90,91$ as maintaining phosphate balance through optimal dietary intake is important for a healthy life and for longevity.7,120,129-134

\section{References}

1. Olauson H, Vervloet MG, Cozzolino M, Massy ZA, Urena Torres P, Larsson TE. New insights into the FGF23-Klotho axis. Semin Nephrol 2014;34:586-97.

2. Brown RB, Razzaque MS. Dysregulation of phosphate metabolism and conditions associated with phosphate toxicity. Bonekey Rep $2015 ; 4: 705$.

3. Sakaguchi Y, Hamano T, Isaka Y. Effects of magnesium on the phosphate toxicity in chronic kidney disease: time for intervention studies. Nutrients 2017;9.

4. Osuka S, Razzaque MS. Can features of phosphate toxicity appear in normophosphatemia? J Bone Miner Metab 2012;30:10-8.

5. Razzaque MS. Phosphate toxicity: new insights into an old problem. Clin Sci (Lond) 2011;120:91-7.

6. Sinha MD, Turner C, Booth CJ, Waller S, Rasmussen P, Goldsmith DJ, Simpson JM. Relationship of FGF23 to indexed left ventricular mass in children with non-dialysis stages of chronic kidney disease. Pediatr Nephrol 2015;30:1843-52.

7. Ritter CS, Slatopolsky E. Phosphate toxicity in CKD: the killer among us. Clin J Am Soc Nephrol 2016;11:1088-100.

8. Camalier CE, Young MR, Bobe G, Perella CM, Colburn NH, Beck Jr GR. Elevated phosphate activates N-ras and promotes cell transformation and skin tumorigenesis. Cancer Prev Res (Phila) 2010;3:359-70.

9. Zhang S, Gillihan R, He N, Fields T, Liu S, Green T, Stubbs JR. Dietary phosphate restriction suppresses phosphaturia but does not prevent FGF23 elevation in a mouse model of chronic kidney disease. Kidney Int 2013;84:713-21.

10. Isakova T, Barchi-Chung A, Enfield G, Smith K, Vargas G, Houston J, Xie H, Wahl P, Schiavenato E, Dosch A, Gutierrez OM, Diego J, Lenz O, Contreras G, Mendez A, Weiner RB, Wolf M. Effects of dietary phosphate restriction and phosphate binders on FGF23 levels in CKD. Clin J Am Soc Nephrol 2013;8:1009-18.

11. Mitch WE, Remuzzi G. Diets for patients with chronic kidney disease, should we reconsider? BMC Nephrol 2016;17:80.

12. Chang AR, Lazo M, Appel LJ, Gutierrez OM, Grams ME. High dietary phosphorus intake is associated with all-cause mortality: results from NHANES III. Am J Clin Nutr 2014;99:320-7.

13. CNPP. MyPlate: Sample Menus for a 2000 Calorie Food Pattern. 2011.

14. USDA/HHS. Dietary Guidelines for Americans 2010. 7th ed. Washington, DC: U.S. Government Printing Office; 2010.

15. Erben RG, Andrukhova O. FGF23-Klotho signaling axis in the kidney. Bone 2017;100:62-8.

16. Kawai M. The FGF23/Klotho axis in the regulation of mineral and metabolic homeostasis. Horm Mol Biol Clin Investig 2016;28:55-67.

17. Martin A, Quarles LD. Evidence for FGF23 involvement in a bone-kidney axis regulating bone mineralization and systemic phosphate and vitamin D homeostasis. Adv Exp Med Biol 2012;728:65-83.

18. Razzaque MS. Osteo-renal regulation of systemic phosphate metabolism. IUBMB Life 2011;63:240-7.

19. Razzaque MS. The FGF23-Klotho axis: endocrine regulation of phosphate homeostasis. Nat Rev Endocrinol 2009;5:611-9.

20. Sabbagh Y. Phosphate as a sensor and signaling molecule. Clin Nephrol 2013;79:57-65.

21. Sabbagh Y, Schiavi SC. Role of NPT2b in health and chronic kidney disease. Curr Opin Nephrol Hypertens 2014;23:377-84.

22. Sabbagh Y, Giral H, Caldas Y, Levi M, Schiavi SC. Intestinal phosphate transport. Adv Chronic Kidney Dis 2011;18:85-90.

23. Giral H, Cranston D, Lanzano L, Caldas Y, Sutherland E, Rachelson J, Dobrinskikh E, Weinman EJ, Doctor RB, Gratton E, Levi M. NHE3 Regulatory Factor 1 (NHERF1) modulates intestinal sodium-dependent phosphate transporter (NaPi-2b) expression in apical microvilli. J Biol Chem 2012;287:35047-56.

24. Sabbagh Y, O'Brien SP, Song W, Boulanger JH, Stockmann A, Arbeeny C, Schiavi SC. Intestinal npt2b plays a major role in phosphate absorption and homeostasis. I Am Soc Nephrol 2009;20:2348-58.

25. Razzaque MS. The dualistic role of vitamin D in vascular calcifications. Kidney Int 2011;79:708-14.

26. Tatsumi S, Miyagawa A, Kaneko I, Shiozaki Y, Segawa H, Miyamoto K-i. Regulation of renal phosphate handling: inter-organ communication in health and disease. J Bone Miner Metab 2016;34:1-10.

27. Imura A, Tsuji Y, Murata M, Maeda R, Kubota K, Iwano A, Obuse C, Togashi K, Tominaga M, Kita N, Tomiyama K, Iijima J, Nabeshima Y, Fujioka M, Asato R, Tanaka S, Kojima K, Ito J, Nozaki K, Hashimoto N, Ito T, Nishio T, Uchiyama T, Fujimori T. alpha-Klotho as a regulator of calcium homeostasis. Science 2007;316:1615-8.

28. Sopjani M, Dermaku-Sopjani M. Klotho-dependent cellular transport regulation. Vitam Horm 2016;101:59-84.

29. Sopjani M, Rinnerthaler M, Almilaji A, Ahmeti S, Dermaku-Sopjani M. Regulation of cellular transport by klotho protein. Curr Protein Pept Sci 2014;15:828-35.

30. Massry SG, Hajjar SM, Koureta P, Fadda GZ, Smogorzewski M. Phosphate depletion increases cytosolic calcium of brain synaptosomes. Am J Physiol 1991;260:F12-8.

31. Brunette MG, el Mernissi G, Doucet A. Renal sodium transport in vitamin D resistant hypophosphatemic rickets. Can J Physiol Pharmacol 1985;63:1339-44. 
32. Miyamoto K, Haito-Sugino S, Kuwahara S, Ohi A, Nomura K, Ito M, Kuwahata M, Kido S, Tatsumi S, Kaneko I, Segawa H. Sodiumdependent phosphate cotransporters: lessons from gene knockout and mutation studies. J Pharm Sci 2011;100:3719-30.

33. Miyamoto K, Ito M, Tatsumi S, Kuwahata M, Segawa H. New aspect of renal phosphate reabsorption: the type IIc sodium-dependent phosphate transporter. Am J Nephrol 2007;27:503-15.

34. Segawa H, Onitsuka A, Shiozawa K, Aranami F, Tatsumi S, Ito M, Kuwahata M, Miyamoto K. Roles of type IIc Na/Pi cotransporters in body Pi homeostasis. J Am Soc Nephrol 2006;17:355A.

35. Segawa H, Kaneko I, Takahashi A, Kuwahata M, Ito M, Ohkido I, Tatsumi S, Miyamoto K. Growth-related renal type II Na/Pi cotransporter. J Biol Chem 2002;277:19665-72.

36. Goto S, Fujii H, Kono K, Watanabe K, Nakai K, Nishi S. Serum FGF23 levels may not be associated with serum phosphate and 1,25-dihydroxyvitamin D levels in patients with Fanconi syndrome-induced hypophosphatemia. Clin Kidney J 2016;9:677-81.

37. Bergwitz C, Juppner H. FGF23 and syndromes of abnormal renal phosphate handling. Adv Exp Med Biol 2012;728:41-64.

38. Lorenz-Depiereux B, Benet-Pages A, Eckstein G, Tenenbaum-Rakover Y, Wagenstaller J, Tiosano D, Gershoni-Baruch R, Albers N, Lichtner P, Schnabel D, Hochberg Z, Strom TM. Hereditary hypophosphatemic rickets with hypercalciuria is caused by mutations in the sodiumphosphate cotransporter gene SLC34A3. Am J Hum Genet 2006;78:193-201.

39. Bergwitz C, Roslin NM, Tieder M, Loredo-Osti JC, Bastepe M, Abu-Zahra H, Frappier D, Burkett K, Carpenter TO, Anderson D, Garabedian M, Sermet I, Fujiwara TM, Morgan K, Tenenhouse HS, Juppner H. SLC34A3 mutations in patients with hereditary hypophosphatemic rickets with hypercalciuria predict a key role for the sodium-phosphate cotransporter NaPi-IIc in maintaining phosphate homeostasis. Am J Hum Genet 2006;78:179-92.

40. Huang X, Jiang Y, Xia W. FGF23 and phosphate wasting disorders. Bone Res 2013;1:120-32.

41. Liao E. FGF23 associated bone diseases. Front Med 2013;7:65-80.

42. Bonewald LF, Wacker MJ. FGF23 production by osteocytes. Pediatr Nephrol 2013;28:563-8.

43. Sun N, Zou H, Yang L, Morita K, Gong P, Shiba T, Akagawa Y, Yuan Q. Inorganic polyphosphates stimulate FGF23 expression through the FGFR pathway. Biochem Biophys Res Commun 2012;428:298-302.

44. Rowe PS. Regulation of bone-renal mineral and energy metabolism: the PHEX, FGF23, DMP1, MEPE ASARM pathway. Crit Rev Eukaryot Gene Expr 2012;22:61-86.

45. Donate-Correa J, Muros-de-Fuentes M, Mora-Fernandez C, Navarro-Gonzalez JF. FGF23/Klotho axis: phosphorus, mineral metabolism and beyond. Cytokine Growth Factor Rev 2012;23:37-46.

46. Prie D, Beck L, Friedlander G, Silve C. Sodium-phosphate cotransporters, nephrolithiasis and bone demineralization. Curr Opin Nephrol Hypertens 2004;13:675-81.

47. Amatschek S, Haller M, Oberbauer R. Renal phosphate handling in human-what can we learn from hereditary hypophosphataemias? Eur J Clin Invest 2010;40:552-60.

48. Villa-Bellosta R, Barac-Nieto M, Breusegem SY, Barry NP, Levi M, Sorribas V. Interactions of the growth-related, type IIc renal sodium/ phosphate cotransporter with PDZ proteins. Kidney Int 2008;73:456-64.

49. Erben RG, Andrukhova O. FGF23 regulation of renal tubular solute transport. Curr Opin Nephrol Hypertens 2015;24:450-6.

50. Fan Y, Bi R, Densmore MJ, Sato T, Kobayashi T, Yuan Q, Zhou X, Erben RG, Lanske B. Parathyroid hormone 1 receptor is essential to induce FGF23 production and maintain systemic mineral ion homeostasis. FASEB J 2016;30:428-40.

51. Andrukhova O, Streicher C, Zeitz U, Erben RG. Fgf23 and parathyroid hormone signaling interact in kidney and bone. Mol Cell Endocrinol 2016;436:224-39.

52. Blau JE, Collins MT. The PTH-Vitamin D-FGF23 axis. Rev Endocr Metab Disord 2015;16:165-74.

53. Lavi-Moshayoff V, Wasserman G, Meir T, Silver J, Naveh-Many T. PTH increases FGF23 gene expression and mediates the high-FGF23 levels of experimental kidney failure: a bone parathyroid feedback loop. Am J Physiol Renal Physiol 2010;299:F882-9.

54. Lanske B, Razzaque MS. Molecular interactions of FGF23 and PTH in phosphate regulation. Kidney Int 2014;86:1072-4.

55. Uwitonze AM, Murererehe J, Ineza MC, Harelimana EI, Nsabimana U, Uwambaye P, Gatarayiha A, Haq A, Razzaque MS. Effects of vitamin D status on oral health. J Steroid Biochem Mol Biol 2017. https://doi.org/10.1016/j.jsbmb.2017.01.020.

56. Razzaque MS. Can adverse effects of excessive vitamin D supplementation occur without developing hypervitaminosis D? J Steroid Biochem Mol Biol 2017. https://doi.org/10.1016/j.jsbmb.2017.07.006.

57. Razzaque MS. FGF23, klotho and vitamin D interactions: what have we learned from in vivo mouse genetics studies? Adv Exp Med Biol 2012;728:84-91.

58. Lanske B, Razzaque MS. Vitamin D and aging: old concepts and new insights. J Nutr Biochem 2007;18:771-7.

59. Razzaque MS, Lanske B. Hypervitaminosis D and premature aging: lessons learned from Fgf23 and Klotho mutant mice. Trends Mol Med 2006;12:298-305.

60. Razzaque MS. Sunlight exposure: do health benefits outweigh harm? J Steroid Biochem Mol Biol 2016. https://doi.org/10.1016/j.jsbmb.2016.09.004.

61. Baggerly CA, Cuomo RE, French CB, Garland CF, Gorham ED, Grant WB, Heaney RP, Holick MF, Hollis BW, McDonnell SL, Pittaway M, Seaton P, Wagner CL, Wunsch A. Sunlight and vitamin D: necessary for public health. J Am Coll Nutr 2015;34:359-65.

62. Holick MF. Vitamin D and sunlight: strategies for cancer prevention and other health benefits. Clin J Am Soc Nephrol 2008;3:1548-54.

63. Holick MF. Sunlight, ultraviolet radiation, vitamin D and skin cancer: how much sunlight do we need? Adv Exp Med Biol 2014;810:1-16.

64. Umbach AT, Zhang B, Daniel C, Fajol A, Velic A, Hosseinzadeh Z, Bhavsar SK, Bock C-T, Kandolf R, Pichler BJ. Janus kinase 3 regulates renal 25-hydroxyvitamin D 1 $\alpha$-hydroxylase expression, calcitriol formation, and phosphate metabolism. Kidney Int 2015;87:728-37.

65. Mattinzoli D, Rastaldi MP, Ikehata M, Armelloni S, Pignatari C, Giardino LA, Li M, Alfieri CM, Regalia A, Riccardi D, Messa P. FGF23regulated production of Fetuin-A (AHSG) in osteocytes. Bone 2016;83:35-47.

66. Murali SK, Roschger P, Zeitz U, Klaushofer K, Andrukhova O, Erben RG. FGF23 regulates bone mineralization in a 1,25(OH)2 D3 and klothoindependent manner. J Bone Miner Res 2016;31:129-42.

67. Kaneko I, Saini RK, Griffin KP, Whitfield GK, Haussler MR, Jurutka PW. FGF23 gene regulation by 1,25-dihydroxyvitamin D: opposing effects in adipocytes and osteocytes. J Endocrinol 2015;226:155-66.

68. Wesseling-Perry K, Juppner H. The osteocyte in CKD: new concepts regarding the role of FGF23 in mineral metabolism and systemic complications. Bone 2013;54:222-9. 
69. Ito N, Wijenayaka AR, Prideaux M, Kogawa M, Ormsby RT, Evdokiou A, Bonewald LF, Findlay DM, Atkins GJ. Regulation of FGF23 expression in IDG-SW3 osteocytes and human bone by pro-inflammatory stimuli. Mol Cell Endocrinol 2015;399:208-18.

70. Urakawa I, Yamazaki Y, Shimada T, Iijima K, Hasegawa H, Okawa K, Fujita T, Fukumoto S, Yamashita T. Klotho converts canonical FGF receptor into a specific receptor for FGF23. Nature 2006;444:770-4.

71. Nakatani T, Ohnishi M, Razzaque MS. Inactivation of klotho function induces hyperphosphatemia even in presence of high serum fibroblast growth factor 23 levels in a genetically engineered hypophosphatemic (Hyp) mouse model. FASEB J 2009;23:3702-11.

72. Nakatani T, Sarraj B, Ohnishi M, Densmore MJ, Taguchi T, Goetz R, Mohammadi M, Lanske B, Razzaque MS. In vivo genetic evidence for klotho-dependent, fibroblast growth factor 23 (Fgf23)-mediated regulation of systemic phosphate homeostasis. FASEB J 2009;23:433-41.

73. Ohnishi M, Kato S, Akiyoshi J, Atfi A, Razzaque MS. Dietary and genetic evidence for enhancing glucose metabolism and reducing obesity by inhibiting klotho functions. FASEB J 2011;25:2031-9.

74. Ohnishi M, Kato S, Razzaque MS. Genetic induction of phosphate toxicity significantly reduces the survival of hypercholesterolemic obese mice. Biochem Biophys Res Commun 2011;415:434-8.

75. Ohnishi M, Nakatani T, Lanske B, Razzaque MS. In vivo genetic evidence for suppressing vascular and soft-tissue calcification through the reduction of serum phosphate levels, even in the presence of high serum calcium and 1,25-dihydroxyvitamin d levels. Circ Cardiovasc Genet 2009;2:583-90.

76. Ohnishi M, Razzaque MS. Osteo-renal cross-talk and phosphate metabolism by the FGF23-Klotho system. Contrib Nephrol 2013;180:1-13.

77. Yamamoto H, Ramos-Molina B, Lick AN, Prideaux M, Albornoz V, Bonewald L, Lindberg I. Posttranslational processing of FGF23 in osteocytes during the osteoblast to osteocyte transition. Bone 2016;84:120-30.

78. Lindberg I, Pang HW, Stains JP, Clark D, Yang AJ, Bonewald L, Li KZ. FGF23 is endogenously phosphorylated in bone cells. J Bone Miner Res 2015;30:449-54.

79. Tan SJ, Satake S, Smith ER, Toussaint ND, Hewitson TD, Holt SG. Parenteral iron polymaltose changes i:c-terminal FGF23 ratios in iron deficiency, but not in dialysis patients. Eur J Clin Nutr 2017;71:180-4.

80. Quarles LD. Skeletal secretion of FGF-23 regulates phosphate and vitamin D metabolism. Nat Rev Endocrinol 2012;8:276-86.

81. Quarles LD. Role of FGF23 in vitamin D and phosphate metabolism: implications in chronic kidney disease. Exp Cell Res 2012;318:1040-8.

82. Martin A, David V, Quarles LD. Regulation and function of the FGF23/klotho endocrine pathways. Physiol Rev 2012;92:131-55.

83. Martin A, David V, Li H, Dai B, Feng JQ, Quarles LD. Overexpression of the DMP1 C-terminal fragment stimulates FGF23 and exacerbates the hypophosphatemic rickets phenotype in Hyp mice. Mol Endocrinol 2012;26:1883-95.

84. Shawar SM, Ramadan AR, Ali BR, Alghamdi MA, John A, Hudaib FM. FGF23-S129F mutant bypasses ER/Golgi to the circulation of hyperphosphatemic familial tumoral calcinosis patients. Bone 2016;93:187-95.

85. Folsom LJ, Imel EA. Hyperphosphatemic familial tumoral calcinosis: genetic models of deficient FGF23 action. Curr Osteoporos Rep 2015;13:78-87.

86. Ichikawa S, Gray AK, Padgett LR, Allen MR, Clinkenbeard EL, Sarpa NM, White KE, Econs MJ. Genetic rescue of glycosylation-deficient Fgf23 in the Galnt3 knockout mouse. Endocrinology 2014;155:3891-8.

87. Farrow EG, Imel EA, White KE. Miscellaneous non-inflammatory musculoskeletal conditions. Hyperphosphatemic familial tumoral calcinosis (FGF23, GALNT3 and alphaKlotho). Best Pract Res Clin Rheumatol 2011;25:735-47.

88. Esapa CT, Hannan FM, Babinsky VN, Potter P, Thomas GP, Croucher PI, Brown MA, Brown SD, Cox RD, Thakker RV. N-ethyl-NNitrosourea (ENU) induced mutations within the klotho gene lead to ectopic calcification and reduced lifespan in mouse models. PLoS One 2015;10:e0122650.

89. Ichikawa S, Imel EA, Kreiter ML, Yu X, Mackenzie DS, Sorenson AH, Goetz R, Mohammadi M, White KE, Econs MJ. A homozygous missense mutation in human KLOTHO causes severe tumoral calcinosis. J Clin Invest 2007;117:2684-91.

90. Shutto Y, Shimada M, Kitajima M, Yamabe H, Saitoh Y, Saitoh H, Razzaque MS. Inadequate awareness among chronic kidney disease patients regarding food and drinks containing artificially added phosphate. PLoS One 2013;8:e78660.

91. Shutto Y, Shimada M, Kitajima M, Yamabe H, Razzaque MS. Lack of awareness among future medical professionals about the risk of consuming hidden phosphate-containing processed food and drinks. PLoS One 2011;6:e29105.

92. Brown RB, Haq A, Stanford CF, Razzaque MS. Vitamin D, phosphate and vasculotoxicity. Can J Physiol Pharmacol 2015.

93. Bello TR, Torbert BJ. Toxicity of an organic phosphate anthelmintic (Shell SD 15803) at excessive dosages in two-month-old pony foals. Am J Vet Res 1972;33:329-34.

94. Uribarri J. Dietary phosphorus and kidney disease. Ann N Y Acad Sci 2013;1301:11-9.

95. Smith ER, Tan SJ, Holt SG, Hewitson TD. FGF23 is synthesised locally by renal tubules and activates injury-primed fibroblasts. Sci Rep 2017;7:3345.

96. Hu MC, Shi M, Gillings N, Flores B, Takahashi M, Kuro OM, Moe OW. Recombinant alpha-Klotho may be prophylactic and therapeutic for acute to chronic kidney disease progression and uremic cardiomyopathy. Kidney Int 2017;91:1104-14.

97. Deng M, Luo Y, Li Y, Yang Q, Deng X, Wu P, Ma H. Klotho gene delivery ameliorates renal hypertrophy and fibrosis in streptozotocininduced diabetic rats by suppressing the Rho-associated coiled-coil kinase signaling pathway. Mol Med Rep 2015;12:45-54.

98. Yamada S, Giachelli CM. Vascular calcification in CKD-MBD: roles for phosphate, FGF23, and klotho. Bone 2017;100:87-93.

99. Cianciolo G, Galassi A, Capelli I, Schillaci R, La Manna G, Cozzolino M. Klotho-FGF23, cardiovascular disease, and vascular calcification: black or white? Curr Vasc Pharmacol 2017.

100. Jimbo R, Shimosawa T. Cardiovascular risk factors and chronic kidney disease-FGF23: a key molecule in the cardiovascular disease. Int J Hypertens 2014;2014:381082.

101. Gross P, Six I, Kamel S, Massy ZA. Vascular toxicity of phosphate in chronic kidney disease: beyond vascular calcification. Circ J 2014;78:2339-46.

102. Faul C, Amaral AP, Oskouei B, Hu MC, Sloan A, Isakova T, Gutierrez OM, Aguillon-Prada R, Lincoln J, Hare JM, Mundel P, Morales A, Scialla J, Fischer M, Soliman EZ, Chen J, Go AS, Rosas SE, Nessel L, Townsend RR, Feldman HI, St John Sutton M, Ojo A, Gadegbeku C, Di Marco GS, Reuter S, Kentrup D, Tiemann K, Brand M, Hill JA, Moe OW, Kuro OM, Kusek JW, Keane MG, Wolf M. FGF23 induces left ventricular hypertrophy. J Clin Invest 2011;121:4393-408. 
103. Adema AY, de Jong MA, de Borst MH, Ter Wee PM, Vervloet MG. Phosphate binding therapy to lower serum fibroblast-growth-factor-23 concentrations in chronic kidney disease: rationale and study design of the Sevelamer on FGF23 Trial (SoFT). Nephron 2016;134:215-20.

104. Soriano S, Ojeda R, Rodriguez M, Almaden Y, Martin-Malo A, Aljama P. The effect of phosphate binders, calcium and lanthanum carbonate on FGF23 levels in chronic kidney disease patients. Clin Nephrol 2013;80:17-22.

105. Rennenberg R, Kessels A, Schurgers L, Van Engelshoven J, De Leeuw P, Kroon A. Vascular calcifications as a marker of increased cardiovascular risk: a meta-analysis. Vasc Health Risk Manag 2009;5:185.

106. Shuto E, Taketani Y, Tanaka R, Harada N, Isshiki M, Sato M, Nashiki K, Amo K, Yamamoto H, Higashi Y. Dietary phosphorus acutely impairs endothelial function. J Am Soc Nephrol 2009;20:1504-12.

107. Foley RN, Collins AJ, Herzog CA, Ishani A, Kalra PA. Serum phosphorus levels associate with coronary atherosclerosis in young adults. J Am Soc Nephrol 2009;20:397-404.

108. Takashi Y, Kinoshita Y, Hori M, Ito N, Taguchi M, Fukumoto S. Patients with FGF23-related hypophosphatemic rickets/osteomalacia do not present with left ventricular hypertrophy. Endocr Res 2017;42:132-7.

109. Seiler S, Cremers B, Rebling NM, Hornof F, Jeken J, Kersting S, Steimle C, Ege P, Fehrenz M, Rogacev KS, Scheller B, Bohm M, Fliser D, Heine GH. The phosphatonin fibroblast growth factor 23 links calcium-phosphate metabolism with left-ventricular dysfunction and atrial fibrillation. Eur Heart J 2011;32:2688-96.

110. Foley RN, Collins AJ, Herzog CA, Ishani A, Kalra PA. Serum phosphate and left ventricular hypertrophy in young adults: the coronary artery risk development in young adults study. Kidney Blood Press Res 2009;32:37-44.

111. Seccia TM, Atlante A, Vulpis V, Marra E, Passarella S, Pirrelli A. Abnormal transport of inorganic phosphate in left ventricular mitochondria from spontaneously hypertensive rats. Cardiologia 1999;44:719-25.

112. Lutsey PL, Alonso A, Michos ED, Loehr LR, Astor BC, Coresh J, Folsom AR. Serum magnesium, phosphorus, and calcium are associated with risk of incident heart failure: the Atherosclerosis Risk in Communities (ARIC) Study. Am J Clin Nutr 2014;100:756-64.

113. Fenninger LD, Waterhouse C, Henry Keutmann E. The interrelationship of nitrogen and phosphorus in patients with certain neoplastic diseases. Cancer 1953;6:930-41.

114. Elser JJ, Kyle MM, Smith MS, Nagy JD. Biological stoichiometry in human cancer. PLoS One 2007;2:e1028.

115. Lin Y, McKinnon KE, Ha SW, Beck GR. Inorganic phosphate induces cancer cell mediated angiogenesis dependent on forkhead box protein C2 (FOXC2) regulated osteopontin expression. Molecular Carcinogenesis 2014.

116. Jansa J, Finlay R, Wallander H, Smith FA, Smith SE. Role of mycorrhizal symbioses in phosphorus cycling. In: Phosphorus in action. Springer; 2011. p. 137-68.

117. Jin H, Xu C-X, Lim H-T, Park S-J, Shin J-Y, Chung Y-S, Park S-C, Chang S-H, Youn H-J, Lee K-H. High dietary inorganic phosphate increases lung tumorigenesis and alters Akt signaling. Am J Respir Crit Care Med 2009;179:59-68.

118. Ramirez CP, Fiedler D. Investigating the role of inorganic phosphate in tumor metabolism and metastasis. Cancer Metab 2014;2:1.

119. Wilson KM, Shui IM, Mucci LA, Giovannucci E. Calcium and phosphorus intake and prostate cancer risk: a 24-y follow-up study. Am J Clin Nutr 2015. http:/ / dx.doi.org/10.3945/ajcn.114.088716.

120. Brown RB, Razzaque MS. Phosphate toxicity: a stealth biochemical stress factor? Med Mol Morphol 2016;49:1-4.

121. Razzaque MS. Phosphate toxicity and vascular mineralization. Contrib Nephrol 2013;180:74-85.

122. Ohnishi M, Razzaque MS. Dietary and genetic evidence for phosphate toxicity accelerating mammalian aging. FASEB J 2010;24:3562-71.

123. Razzaque MS. Does renal ageing affect survival? Ageing Res Rev 2007;6:211-22.

124. Zha Y, Taguchi T, Nazneen A, Shimokawa I, Higami Y, Razzaque MS. Genetic suppression of GH-IGF-1 activity, combined with lifelong caloric restriction, prevents age-related renal damage and prolongs the life span in rats. Am J Nephrol 2008;28:755-64.

125. Zha Y, Le VT, Higami Y, Shimokawa I, Taguchi T, Razzaque MS. Life-long suppression of growth hormone-insulin-like growth factor I activity in genetically altered rats could prevent age-related renal damage. Endocrinology 2006;147:5690-8.

126. Razzaque MS. Bone-kidney axis in systemic phosphate turnover. Arch Biochem Biophys 2014;561:154-8.

127. Razzaque MS. FGF23-mediated regulation of systemic phosphate homeostasis: is Klotho an essential player? Am J Physiol Renal Physiol 2009;296:F470-6.

128. Razzaque MS. Does FGF23 toxicity influence the outcome of chronic kidney disease? Nephrol Dial Transplant 2009;24:4-7.

129. Goodson JM, Shi P, Mumena CH, Haq A, Razzaque MS. Dietary phosphorus burden increases cariogenesis independent of vitamin D uptake. J Steroid Biochem Mol Biol 2017;167:33-8.

130. Hartman ML, Groppo F, Ohnishi M, Goodson JM, Hasturk H, Tavares M, Yaskell T, Floros C, Behbehani K, Razzaque MS. Can salivary phosphate levels be an early biomarker to monitor the evolvement of obesity? Contrib Nephrol 2013;180:138-48.

131. Memon F, El-Abbadi M, Nakatani T, Taguchi T, Lanske B, Razzaque MS. Does Fgf23-klotho activity influence vascular and soft tissue calcification through regulating mineral ion metabolism? Kidney Int 2008;74:566-70.

132. Razzaque MS, Lanske B. The emerging role of the fibroblast growth factor-23-klotho axis in renal regulation of phosphate homeostasis. $J$ Endocrinol 2007;194:1-10.

133. Lanske B, Razzaque MS. Mineral metabolism and aging: the fibroblast growth factor 23 enigma. Curr Opin Nephrol Hypertens 2007;16:311-8.

134. Majunder SK, Bano A. Toxicity of calcium phosphate to some pests of stored grain. Nature 1964;202:1359-60.

135. Razzaque MS. Can fibroblast growth factor 23 fine-tune therapies for diseases of abnormal mineral ion metabolism? Nat Clin Pract Endocrinol Metab 2007;3:788-9. 